\title{
Thinking about the Firm: A Review of Daniel Spulber's the Theory of the Firm
}

\section{Citation}

Hart, Oliver. 2011. “Thinking about the Firm: A Review of Daniel Spulber's The Theory of the Firm." Journal of Economic Literature49 (1): 101-13. https://doi.org/10.1257/jel.49.1.101.

\section{Permanent link}

http://nrs.harvard.edu/urn-3:HUL.InstRepos:41534610

\section{Terms of Use}

This article was downloaded from Harvard University's DASH repository, and is made available under the terms and conditions applicable to Other Posted Material, as set forth at http:// nrs.harvard.edu/urn-3:HUL.InstRepos:dash.current.terms-of-use\#LAA

\section{Share Your Story}

The Harvard community has made this article openly available.

Please share how this access benefits you. Submit a story. 


\title{
Thinking about the Firm: A Review of Daniel Spulber's The Theory of the Firm
}

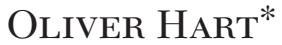

In this review, I describe how economists have moved beyond the firm as a black box to incorporate incentives, internal organization, and firm boundaries. I then turn to the way that the theory of the firm is treated in Daniel Spulber's book The Theory of the Firm: Microeconomics with Endogenous Entrepreneurs, Firms, Markets, and Organizations. Spulber's goal is to explain why firms exist, how they are established, and what they contribute to the economy. To accomplish this, Spulber defines a firm to be a transaction institution whose objectives differ from those of its owners. For Spulber, this separation is the key difference between the firm and direct exchange between consumers. I raise questions about whether this is a useful basis for a theory of the firm. (JEL D21)

\section{Introduction}

$F^{i}$ irms are an essential part of the economy. However, as Daniel Spulber points out in The Theory of the Firm: Microeconomics with Endogenous Entrepreneurs, Firms, Markets, and Organizations (Cambridge University Press 2009), the modern firm is a relatively recent phenomenon. From the earliest times to the eighteenth century, business was carried out by farmer, artisans, and merchants (Spulber, p. 103). According to Alfred D. Chandler, merchants still ruled the (American) economy in 1790. The family

\footnotetext{
* Harvard University. I am very grateful to Phillippe Aghion, Bengt Holmstrom, Andrei Shleifer, and Luigi Zingales for helpful comments and to Jonathan Hall for research assistance. Research support from the National Science Foundation through the National Bureau of Economic Research is gratefully acknowledged.
}

remained the basic business unit. The general merchant bought and sold all types of products and carried out all the basic commercial functions. By the 1840s, such tasks were being carried out by different types of specialized enterprises. However, it was still true that these enterprises were personally managed by their owners or by managers who worked closely with the owners. It was only in the second half of the nineteenth century that the world saw the emergence of the modern corporation, a multiunit enterprise operated by teams of salaried managers who had little or no equity in the firm (Chandler 1977, p. 17; Chandler 1990, pp. 1, 14). [1]

Today, of course, the large company is ubiquitous and often operates in multiple

\footnotetext{
${ }^{1}$ See also Adolf A. Berle and Gardiner C. Means (1932).
} 
countries. Many people work in such companies. In 2007, Wal-Mart, the largest U.S. employer, had 1.8 million employees. ${ }^{\text {目 }}$ In 2001, a randomly selected employee in the United Kingdom worked in a firm with 934 other employees. ${ }^{-1}$ But, in spite of the fact that large public companies dominate the economic landscape in advanced countries, there are many other types of firms that are still important: sole proprietorships, family-owned enterprises, partnerships, cooperatives, mutuals, nonprofits, and government-owned firms. ${ }^{\text {. }}$ This raises a natural question: should we be looking for one theory that encompasses all of these forms? Or should we be looking for several different theories?

One problem any economist faces in analyzing the firm is one of definition. To pose a question that is often asked but rarely answered (at least satisfactorily) —what is a firm? Is a firm circumscribed by its legal status or by its economic activities? This question is quite important if, for example, one wishes to understand the motives for mergers. The fact that this question is so difficult to answer may be one reason that the theory of the firm is one of the less developed and agreed-upon areas of economics. The theory of the consumer does not suffer from the same problem. Although individuals may be infinitely complicated, at least we know what their boundaries are.

In this review, I will describe what I see as the current state of the theory of the firm and what the main unresolved questions are. It goes without saying that my focus is selective. I will not, for example, discuss the very large

\footnotetext{
2 There are over 64,000 multinational firms that operate across national boundaries and the foreign affiliates of multinational firms employ more than 53 million people. See Spulber, p. 110.

3 http://www.walmartfacts.com/featuredtopics/?id=3, accessed February 2, 2007.

4 See Oliver Hart (2008).

5 There are approximately 20 million firms in the United States (Spulber, p. 110). Approximately 6,500 firms are traded on the three major U.S. stock exchanges (see CRSP US Stock Databases).
}

literature on organizations by noneconomists, in particular sociologists and organizational behavior theorists. This literature is undoubtedly interesting and important in its own way, but my opinion is that it is not yet at a stage of theoretical or empirical precision that it can be incorporated into mainstream economic thinking. I will also only touch on the vast literature on firms' financing decisions.

After discussing the state of the literature, I will turn to how the theory of the firm is treated in Daniel Spulber's new book.

\section{The Textbook View of the Firm}

In most modern microeconomic textbooks, the firm is still represented in purely technological terms as a production function or production set. ${ }^{6}$ The firm is presided over by a manager who acts on behalf of the owners. Since the firm is typically supposed to operate under perfect competition and there is a complete set of markets, the owners unanimously want the manager to maximize profit or market value-this increases their wealth and their set of consumption possibilities-and this is what he is supposed to do.

While this is a caricature of the modern firm, there is no doubt that it is a very useful one. The approach can be used to understand how firms' production choices respond to changes in prices and taxes and to predict the aggregate behavior of an industry. Moreover, once the assumption of perfect competition is dropped, the approach can be used to study the strategic interaction between firms. In fact, a large part of the modern industrial organization literature relies on the production function view of the firm.

6 See, e.g., Walter Nicholson and Christopher Snyder (2006).

7 See, e.g., Jean Tirole (1988). Note that, even under imperfect competition, the assumption that the owners of the firm want it to maximize profit or market value can be justified if each owner consumes a negligible amount of the firm's product. Spulber discusses this in chapter 3. 
However, for many purposes, this view of the firm is inadequate. For example, it has little if anything to say about optimal executive compensation or about firms' financing decisions. It also does not help us to understand the determinants of firm boundaries or the internal organization of large firms, or why some firms are cooperatives, or the nature of the contracts that firms write with each other. In the 1970s and 1980s, there was an explosion of work in response to these limitations. Let me turn to this.

\section{Opening the Black Box: Incentives}

The textbook model supposes that the manager is an automaton who acts in the owners' interest. One way to enrich the basic model is to allow for the possibility that the manager has goals of his own. For example, the manager may like the easy life, or may enjoy perks, or may be an empire builder. The owners would like to prohibit these activities to the extent that they interfere with value maximization but, if some of the manager's actions are hidden or the manager has private information about his environment, this may be impossible. As a result, the goal of profit or value maximization will not be achieved. ${ }^{\S}$

The conflict of interest between managers and owners is the focus of the by now vast principal-agent literature. In the early moral hazard models of James A. Mirrlees (1999) and Bengt Holmstrom (1979), the manager is supposed to be risk averse and the optimal compensation contract trades off incentives

\footnotetext{
8 In focusing on the conflict of interest between owners and managers, I am taking a rather U.S. or U.K.centric view of the world. In many countries, there is little separation between ownership and management; see Rafael La Porta, Florencio Lopez-de-Silanes, and Andrei Shleifer (1999). For firms in such countries, the more relevant conflict may be between managers and workers.
}

and risk sharing. ${ }^{\text {B }}$ In more recent work, the emphasis has been on getting the agent to take the right kind of action (see Holmstrom and Paul Milgrom 1991). ${ }^{10}$ In this multitasking literature, high-powered incentives are costly not because they expose the manager to too much risk but because they cause the manager to focus on the wrong kinds of activities from the owners' perspective. For example, the manager on a high-powered incentive scheme may be so concerned to increase his wealth that he might engage in dubious practices, such as manipulating the accounts. This will be a particular problem if the manager expects to leave the firm and his incentives are short-term. We saw some of the negative consequences of account manipulation in Enron and related cases in the early 2000 s.

In the one period moral hazard model, the optimal incentive scheme may be complex; for example, it may be highly nonlinear. In a multiperiod environment, however, this can lead to gaming as the manager moves profit from one period to another to maximize the marginal impact on his incentives. Under some conditions, Holmstrom and Milgrom (1987) show that, in a dynamic environment, the optimal incentive scheme is linear. As a practical application, this would suggest that it might make sense to allocate equity rather than stock options to managers. Stock options discourage managerial effort if the options are "out of the money." Of course, if they are "far out of the money," they may also encourage excessive risk taking.

\footnotetext{
${ }^{9} \mathrm{~A}$ related part of the literature supposes that the manager has precontractual private information. See chapter 2 of Patrick Bolton and Mathias Dewatripont (2005) for a summary.

${ }^{10}$ See George P. Baker (1992) for related work. Another important extension, carried out by Holmstrom (1982), has been to the case of multiple agents and the free rider problems that arise when there is team production (see also Armen A. Alchian and Harold Demsetz 1972). Tirole (1986) studies collusion in the presence of multiple agents.
} 
A parallel literature to the principal-agent one was developed in corporate finance at about the same time in order to explain a firm's financial structure. In the textbook model, where the manager acts on behalf of shareholders and markets are complete, the Modigliani-Miller theorem tells us that financial structure is irrelevant in the absence of taxes (see Franco Modigliani and Merton H. Miller 1958). To explain financial structure, Michael C. Jensen and William H. Meckling (1976) suppose that managers like perks (fancy offices, corporate jets, etc.). They consider a manager who initially owns 100 percent of a firm. In this situation, the manager will have no incentive to take excessive perks since he bears the full consequences of such behavior. But now suppose the firm has to raise capital. One way to do this is to issue equity. However, this will dilute the manager's stake and, since he is no longer the 100 percent residual income claimant, he will start to behave inefficiently: a dollar spent on perks may be worth less than a dollar to the manager, but it may still be worth more than a dollar in dividends that has to be shared with outside shareholders. It might be better for the firm to borrow since this keeps the manager's equity stake intact: as the 100 percent residual claimant, he bears the full consequences of inefficient behavior. At the same time if the firm borrows too much, then the debt will become risky and this will encourage the manager to gamble with the company's funds: the upside of such a gamble is enjoyed by the equityholders, that is, the manager, while the downside losses are borne by the creditors. The optimal mix of debt and equity trades off these effects.

It is interesting that Jensen and Meckling use classic principal-agent ideas to derive implications about optimal capital structure rather than optimal incentive schemes. The relationship between capital structure and incentive schemes and the extent to which agency and information problems explain the use of one rather than the other is still a somewhat unresolved issue in the corporate finance literature. In practice, both seem to be important to control managerial misbehavior.

In the standard principal-agent literature, it is usually supposed that the owner chooses the optimal incentive scheme. But, in the context of a large public company, shareholders are often dispersed and managers are in charge (with some constraints imposed by the board of directors). In this case, it is more natural to suppose that managers choose the incentive scheme and in some cases also the capital structure. ${ }^{11}$ Not surprisingly, the implications of this are significant. For example, if managers choose their own incentive scheme, they may opt for high pay rather than (high) pay for performance. This issue has been relevant in the recent debate on executive compensation. 12

\section{Opening the Black Box: Firm Boundaries}

The textbook view of the firm takes firm boundaries as given. The firm is associated with a production set but it is not asked where this comes from. Yet, in practice, firm boundaries are constantly changing. Firms are continually merging and demerging, outsourcing and insourcing. In 2006, the worldwide value of mergers and acquisitions exceeded $\$ 4$ trillion. ${ }^{13}$ What determines this activity?

The analysis of this issue began with Ronald H. Coase's famous 1937 article on the nature of the firm, and two Nobel prizes have now been awarded for work in this area: one to Coase in 1991 and another to

11 See Jeffrey Zwiebel (1996).

12 See, e.g., Lucian Bebchuk and Jesse Fried (2004).

${ }^{13}$ See The Economist, "Mergers and Acquisitions," January 13, 2007. http://www.economist.com/node/8522024. 
Oliver E. Williamson in 2009. Coase first raised the question of why any transactions take place in firms if markets are so good at allocating resources. Coase suggests that the answer is that using the market is costly. The two most important costs are (i) discovering what the market prices are and (ii) negotiating a contract for each exchange transaction. According to Coase, these costs are avoided inside the firm because bargaining is replaced by authority: an employer tells an employee what to do and (within limits) the employee obeys. However, authority has its own costs. First, as a firm gets bigger, the entrepreneur or manager running it will find it increasingly difficult to organize the firm's activities given his or her limited (intellectual) capacity. Second, and related to this, the person in charge will make mistakes.

Coase's questions about why firms and markets coexist are brilliant, but his answers are less satisfactory and it has been left to others to make progress. To mention one problem: why cannot an overstretched manager hire another manager to help him out? Also, it seems optimistic and unrealistic to suppose that placing a transaction inside a firm eliminates all haggling: there are many examples in practice of serious and costly disagreements inside firms.

In the 1970s, Williamson (1971, 1975), and later Benjamin Klein, Robert G. Crawford, and Alchian (1978), made significant progress on understanding the costs of using markets. Williamson focused on a situation where parties make relationship-specific investments. These are investments that are worth more inside a relationship than outside. A classic example is an electricitygenerating plant that sites near a coal mine. Ideally, a transaction involving relationshipspecific investments would be governed by a long-term contract but, in practice, such contracts are hard to write because of the difficulties of anticipating the future. Any such contract will be incomplete and will have to be revised or renegotiated ex post. Williamson argues that this renegotiation process is costly. The parties will engage in opportunistic and wasteful behavior to improve their bargaining position. Given the presence of private information, renegotiation may fail altogether. As a result, a considerable amount of surplus may be lost.

Williamson and Klein, Crawford, and Alchian argue that, in circumstances like these, it might be more efficient for the parties to vertically integrate, that is, to carry out the transaction under the umbrella of a single firm. Within a single firm, bargaining is replaced by authority. As in Coase (1937), an employer tells an employee what to do and within limits he obeys. There is a considerable amount of empirical evidence consistent with the conclusion that vertical integration is a likely outcome in the presence of large relationship-specific investments. ${ }^{14}$

The theories of Williamson and Klein, Crawford, and Alchian are largely informal and leave open important questions such as how authority is enforced in an integrated firm, what the costs of integration are, and even what integration means. In a 1986 paper, Sanford J. Grossman and I developed a framework for answering these questions (Grossman and Hart 1986; see also Hart and John Moore 1990). We argued that an implication of contractual incompleteness is that not all decisions that have to be made in a relationship will be fully specified in the initial contract. A key question is: who makes the unspecified decisions? We argued that the owner of a nonhuman asset has the right to decide how the asset should be used in circumstances not covered by the contract: the owner has residual rights of control. We also identified a firm with the nonhuman assets it possesses.

\footnotetext{
14 See the survey by Francine Lafontaine and Margaret Slade (2007).
} 
Our approach yields a theory of asset ownership and firm boundaries. In our formal model, parties renegotiate their incomplete contract once an uncontracted-for contingency arises: this renegotiation occurs under symmetric information (both observe the contingency). The parties therefore reach an ex post efficient outcome. However, the division of surplus depends on the allocation of asset ownership. Suppose you and I can both undertake noncontractible investments that make us more productive as long as we have access to asset $A$. If I own $A$, then I can use my residual control rights to deny you access ("hold you up"), thereby reducing your share of the ex post surplus. Under reasonable assumptions, this will reduce your incentive to invest. On the other hand, if you own asset $A$, then you can use your residual control rights to hold me up, and knowing this I will invest less. Under plausible assumptions, it can be shown that ownership of asset A should be allocated to the party whose investment is more important.

The theory explains why it is better for an agent sometimes to be an independent contractor (own the asset she works with) and sometimes to be an employee (not own the asset). No individual should own all the assets and similarly there should not be a single firm in the economy that owns everything.

The Grossman-Hart-Moore (GHM) or property rights-model is an operational vehicle for analyzing the costs and benefits of integration, and I think that it is fair to say that it has become a workhorse in the literature. It provides useful comparative statics properties and has implications concerning the ownership of synergistic assets. Also, there is by now a fair amount of evidence consistent with the implication of GHM that one of the costs of integration is that it is hard to elicit efficiencyenhancing investments from employees. ${ }^{15}$ At

15 See Lafontaine and Slade (2007). the same time, the model is restrictive in that it is based on efficient ex post renegotiation, which means that it is unlikely to be helpful in understanding the internal organization of large companies (see below). 16

In recent work with coauthors, I have tried to broaden the property rights approach so that it can cast light on internal organization (see Hart and Moore 2008, Hart 2009, and Hart and Holmstrom 2010). In these newer models, which use some behavioral ideas, allocations are ex post inefficient and the allocation of authority matters (see below). In a sense, this work can be viewed as a "merger" of the transaction cost and property rights literatures. Whether this merger will be successful remains to be seen.

\section{Opening the Black Box: What Goes on Inside the Firm}

Lafontaine and Slade (2007) have estimated that the value of transactions in U.S. firms is approximately equal to that in U.S. markets. Raghuram G. Rajan and Luigi Zingales (1998) have found, in a sample of forty-three countries, that two thirds of the growth in industries over the 1980s came from growth in the size of existing firms. Thus it is clear that a great deal of economic activity takes place inside firms.

\footnotetext{
16 One advantage of the more formal approach in GHM is that it may help to answer some questions that an informal approach cannot. Suppose a firm creates a new entity out of some of its operations but retains complete control over the new entity. Is it easier to motivate workers in the new entity than when they were in-house employees? According to GHM, the answer is no: nothing has changed. I'm not sure what more informal approaches would say about this. I was involved in a legal case along these lines. In Black and Decker v. U.S.A., Black and Decker argued that they created a new entity to manage employee and retiree health care benefits for efficiency rather than tax reasons. I argued for the U.S. government that there was no efficiency rationale since control did not change. The case was settled. More recently, I was involved in a second case, WFC Holdings (Wells Fargo) v. U.S.A., which raised similar issues. This case went to trial (a verdict is awaited).
} 
Explaining the organization of this activity would seem to be an important goal for economists. ${ }^{17}$ Unfortunately, while there is a massive literature on these issues, progress has been slow in the sense that there is no consensus on the best models to use. One problem is that most models in this area fail to distinguish between inter- and intra-firm transactions.

One part of the literature studies how production, information collection and processing, and communication tasks should be allocated given that no single person knows or can do everything. Papers in this area include Roy Radner (1992), Radner and Timothy van Zandt (1992), Bolton and Dewatripont (1994), and Luis Garicano (2000). This part of the literature follows the team-theoretic approach of Jacob Marschak and Radner (1972) in supposing that all members of the team have the same objective function. It is typically assumed that members of the same team work in a single organization but it is not explained why. Thus this work does not inform us directly about internal organization: it tells us as much about how society does or should solve task assignment problems as about how firms do.

A second part of the literature studies the allocation of decision rights. As background, it is useful to remember that legal control rights in (most) large organizations reside with the board of directors (typically elected by the owners). Thus any allocation of authority to someone inside an organization is temporary or provisional: the board of directors always has the legal right to take the decision back at a moment's notice. To use Baker, Robert Gibbons, and Kevin J. Murphy's felicitous language, inside an

\footnotetext{
${ }^{17}$ An interesting account of recent trends in the internal organization of large companies can be found in John Roberts (2004). For some recent empirical work on the determinants of internal organization, see Daron Acemoglu et al. (2007) and Nicholas Bloom and John Van Reenen (2007).
}

organization decision rights are "loaned, not owned" (Baker, Gibbons, and Murphy 1999).

Call the loaning of decision rights the formal allocation of authority. (That is, formal authority is temporary legal authority.) An example would be someone being allocated a budget to purchase equipment. How should such decision rights be allocated? Bolton and Dewatripont (1995) use team theory to study this question. They consider a situation where subordinates have more information than a boss. The boss can ask the subordinates to transmit their information but this is costly and takes time. Alternatively, the boss can forego communication and let the subordinates decide themselves. Bolton and Dewatripont show that centralization will be preferred to decentralization if decisions in the organization are highly interrelated but not if they are independent.

Jensen and Meckling (1992) analyze a similar situation but introduce a conflict of interest between subordinates and bosses. They emphasize that lower down members of an organization have better information than their bosses but may have the wrong goals. The advantage of centralization is that the boss will maximize the right thing; the disadvantage is that she will be uninformed. Wouter Dessein (2002) and Ricardo Alonso, Dessein, and Niko Matouschek (2008) extend this type of analysis to the case where the boss can elicit information from the subordinates so as to improve her decision making, and where their willingness to report truthfully may depend on whether they have been delegated some decision rights.

These papers do not consider firm boundaries. The members of the organization could be agents in different firms. In other words, the results could be telling us about the allocation of decision rights across several firms rather than within a single firm.

Philippe Aghion and Tirole (1997) is the first paper to develop a theory of authority that takes into account firm boundaries. 
Aghion and Tirole argue that a boss can credibly allocate authority to someone by overloading herself so that she is less informed than this person, and that this may be a way to motivate subordinates to generate ideas: if the boss is uninformed, subordinates know that their ideas will usually be implemented. That is, even though the boss has legal authority, the subordinate has "real" authority in the sense that the subordinate gets his way. Aghion and Tirole show that, in some cases, it may be better to motivate subordinates through the vehicle of real authority than by transferring legal authority to them.

Aghion and Tirole's theory is about the choice between real and legal authority rather than about formal authority in the way that we have defined it here. In their model, temporary legal authority is not an effective way to motivate someone since the boss can always take back the authority ex post (unless reputational forces are at work; see Baker, Gibbons, and Murphy 1999). Hart and Holmstrom (2010) give formal authority a role by introducing a friction. Their paper, which builds on Hart and Moore (2008), supposes that a reversal of formal authority causes subordinates to feel aggrieved and to shade on performance. This discourages a boss from reversing a prior allocation, and so the allocation of formal authority serves as a commitment device. Hart and Holmstrom (2010) show that the delegation of authority within an integrated firm can be a useful compromise between fully centralized integration and nonintegration: delegation allows subordinates to get their way when decisions mean more to them than to the boss, while the boss can always reverse if the outcome is sufficiently important to her.

\section{Daniel Spulber's New Book}

Daniel Spulber is the author of many books and articles on the firm and related topics, and is the founding editor of the Journal of
Economics and Management Strategy. He has obviously thought a lot about firms.

Before I describe his perspective, let me note that there is much of interest in this book. Spulber has a broad view of the theory of the firm and he includes interesting discussions of the history of the firm as an institution and legal aspects of the firm, going back to partnership law in the Roman Empire. Many readers will not have been exposed to this material and will find it very useful.

When I started to read Spulber's book, I expected that he would emphasize topics 3-5 above. But he does not. These topics are mentioned but they are not the focus of the book. Spulber's perspective is different.

Spulber's goal in writing his book is stated right away: "The Theory of the Firm seeks to explain (1) why firms exist, (2) how firms are established, and (3) what firms contribute to the economy" (p. ix). To accomplish this goal, Spulber needs a definition of a firm. Here it is: "The firm is defined to be a transaction institution whose objectives differ from those of its owners. The separation is the key difference between the firm and direct exchange between consumers" ( $p$. 63). Spulber uses this definition to argue that consumer organizations such as clubs and basic partnerships are not firms. The reason is that "the objectives of consumer organizations cannot be separated from those of their owners" (p. ix). Similarly, many family businesses are not firms, and nor are worker cooperatives, nonprofit organizations, or public enterprises (chapter 1, pp. 42-61). At the same time, clubs (and worker and consumer cooperatives and partnerships) become firms if and when a market is created in memberships.

The intellectual stimulus for Spulber's approach is Irving Fisher's famous separation theorem (Fisher 1930). Fisher addressed the separation of the firm's investment decisions from owners' consumption and savings 
objectives. As Spulber says: "Under reasonable assumptions the firm's optimal investment decisions are independent of the preferences of its owners and independent of how the investment is financed" (p. 65). The firm's owners are affected by the firm's decisions only through their wealth. We appealed to a version of this theorem in section 2 when we justified the assumption that firms maximize profit.

The Fisher separation theorem is obviously important but it is not clear that it provides a good basis for defining a firm. There are some very important institutions in the United States that almost everyone would regard as firms, but it is not clear that they pass the Spulber test. Bill Gates is still a significant owner of and quite involved in Microsoft, so is Microsoft a firm? Larry Page and Sergey Brin are significant owners of and (even more) involved in Google, so is Google a firm? Will these organizations become firms only when their founders are long gone? Similar questions arise in varying degrees with respect to other companies with large and active owners, e.g., News Corporation, Berkshire Hathaway, CBS, and the New York Times.

Apart from the fact that many natural firms seem to fail the test, there is also the question of how to apply the test. How can we say empirically whether an entity has an objective function that differs from that of its owners? How do we learn what the objective function of a firm is? Should we ask the CEO? A representative member of the organization? More generally, does it even make sense to talk about the objective function of an organization? Jensen and Meckling are dismissive of the idea in their well-known 1976 article. They argue that “. . . the personalization of the firm implied by asking questions such as "what should be the objective function of the firm' . . . is seriously misleading. The firm is not an individual. It is a legal fiction which serves as a focus for a complex process in which the conflicting objectives of individuals . . . are brought into equilibrium within a framework of contractual relations" (p. 311). Even if Jensen and Meckling go too far-the New York Times, for example, probably has some fairly well-defined goals, and many firms seem to have significant corporate cultures-it is not clear that the concept of an objective function is a valid basis for a theory of the firm.

Nor is it clear that Spulber's test is empirically relevant. Suppose that I want to know whether a public company $A$ is likely to engage in value-reducing acquisitions. We know from much research in corporate finance ${ }^{\text {Is }}$ that it may be significant whether company $A$ has a large shareholder or whether company A's CEO has substantial stock options, but whereas the first may disqualify the company as a firm according to Spulber's test, the second does not.

It is also not obvious that Spulber's definition yields useful theoretical trade-offs or insights. Let's consider one of Spulber's leading examples, a worker cooperative. In chapter 6, Spulber starts by describing Benjamin Ward's (1958) basic model of a cooperative. Suppose that identical workers are each endowed with one unit of labor and can earn a market wage $w$. There is a technology described by the production function

$$
Q=F(L),
$$

where $L$ is labor and $Q$ is output and $F^{\prime}>0$, $F^{\prime \prime}<0$. Output is sold at a competitive price $p$. There is a fixed cost of production $K$.

The worker cooperative chooses employment $L$ to maximize each member's share of surplus,

$$
\frac{p F(L)-K}{L} .
$$

18 See, e.g., Randall Morck, Shleifer, and Robert W. Vishny (1988). 
The first order conditions are

$$
\frac{p F(\hat{L})-K}{\hat{L}}=p F^{\prime}(\hat{L}) .
$$

In other words, the average revenue product of labor is equated to the marginal revenue product. The partnership is viable at the scale $\hat{L}$ only if each member receives more than her outside option:

$$
\frac{p F(\hat{L})-K}{\hat{L}} \geq w,
$$

which we assume in what follows.

Call the above the "basic" worker cooperative. Compare this to a standard profit-maximizing firm that chooses an employment level satisfying

$$
p F^{\prime}\left(L^{*}\right)=w .
$$

It is easy to show that $\hat{L} \leq L^{*}$. That is, a worker cooperative operates at an inefficiently low scale. The reason is that, given equal treatment of members, the cooperative has to share surplus with new members, which means that increasing employment is expensive.

As Spulber points out, there is a simple solution to this inefficiency: the cooperative can charge a membership fee. Assume that the initial owners possess $n$ units of labor themselves, where $n \leq L^{*}$. Suppose they hire $L-n$ new members and charge each a membership fee $f$. Given that surplus is shared equally, $f$ can be set such that

$$
\frac{p F(L)-K}{L}-w=f,
$$

and so each original owner obtains

$$
\text { (7) } \begin{aligned}
& \frac{p F(L)-K}{L}+\left(\frac{L-n}{n}\right) f \\
& =\frac{1}{n}[p F(L)-w L-K]+w .
\end{aligned}
$$

Clearly (7) is maximized by setting $L=L^{*}$. Moreover, the original owners are better off than if they did not use a membership fee and set $L=\hat{L}$.

Another equally good option for the owners is to sell their technology to an outsider for $p F\left(L^{*}\right)-w L^{*}-K$ and let her run it as a profit-maximizing firm.

What do we conclude from this? Spulber deduces that we should not describe the basic worker cooperative (without a membership fee) as a firm since its objective cannot be separated from that of its owners; while the worker cooperative with a membership fee (and of course the standard profit-maximizing firm) is a firm since the Fisher separation criterion is satisfied. My conclusion is different. I think that both forms of worker cooperative (as well, of course, as a profitmaximizing firm) are firms, but one form is more efficient than the other. If the world is as described above, then in equilibrium we would expect to see the basic worker cooperative being replaced by one with membership fees or by a profit-maximizing firm. Moreover, for me the intellectual underpinning of this result is not so much the Fisher separation theorem as the Coase theorem (Coase 1960).

In this simple setting of perfect information and perfect contracts, the basic worker cooperative is never optimal. Nor is what Spulber calls a club. To understand why clubs and worker cooperatives are sometimes observed, Spulber introduces two alternative assumptions. The first is that there is a transaction cost of setting up a profit-maximizing firm or introducing membership fees. The second is that there is asymmetric information. The implications of the first are obvious. To understand the second, consider the case where there is not a single market wage $w$. Instead, the opportunity costs of workers are idiosyncratic and are known only to them. Then a profit-maximizing firm, or a cooperative that sets entry fees, may cause 
inefficiency by trying to price (or wage) discriminate between workers. A basic cooperative that simply opens its doors to anyone who wants to join up to a certain limit might be more efficient.

Indeed there is a small but growing literature in organizational economics that studies the circumstances in which "nonstandard" forms such as consumer cooperatives, worker cooperatives, nonprofits, or publicly owned firms perform better than standard for-profit firms. 19 Much of this literature is influenced by Henry Hansmann's 1996 book and examples include Ryan Bubb and Alex Kaufman (2009), Hart and Moore (1996), Hart, Shleifer, and Vishny (1997), Edward L. Glaeser and Shleifer (2001), and Jonathan Levin and Steven Tadelis (2005). This literature treats all these "nonstandard" forms as firms but distinguishes between them either on the basis of who has voting rights and can therefore choose the firm's policy or on the basis of the incentive schemes they are likely to use (the idea is that a nonprofit can more credibly commit to a low-powered incentive scheme than a for-profit). While Spulber cites quite a bit of this literature, he does not really use it.

The point is that the modern literature tries to derive the behavior of organizations from primitives such as governance structure or managerial incentives. It does not suppose that different organizations have different objective functions.

There is much more in Spulber's book than I have covered. There is interesting material on the neglected role of the entrepreneur in economics as well as chapters on the firm as an intermediary and a marketmaker. For Spulber, entrepreneurs play a central role because they are the prime movers in creating firms. An individual decides

\footnotetext{
19 The discussion about the merits of including a public option in U.S. health insurance shows that this is a topical issue.
}

to become an entrepreneur on the basis of market opportunities and individual preferences, endowments, and other characteristics. The individual is an entrepreneur during the period in which he devotes effort and resources to establishing a firm. If the entrepreneur succeeds in establishing a firm, he then becomes an owner of the firm. The value of the ownership rights provides the basis for the returns to the entrepreneur.

Spulber introduces the concept of the foundational shift (p. 152). Before the foundational shift occurs, the objectives of the startup enterprise cannot be separated from those of the entrepreneur. The startup enterprise is not fully formed for this reason. After the foundational shift occurs, the firm is established and the entrepreneur becomes an owner of the firm.

Spulber is clearly right that entrepreneurs are important in setting up firms and that their reward often comes from their ownership stake. However, aren't the people who set up a school, university, journal, or golf club entrepreneurs too? And isn't this true even if the behavior of these institutions is always influenced by the preferences of their trustees, board, editors, members; in other words, even if a foundational shift never occurs?

\section{Conclusions}

I have described what I see as some of the key issues in the theory of the firm and also how this topic is dealt with in Daniel Spulber's book. The overlap is not great. It is possible that there will be some convergence in the future. For example, firms have cultures and norms that can be very important. ${ }^{20}$ Given this, different firms may behave as if they have different objective functions. This raises the question: should we take a

${ }^{20}$ See, e.g., David M. Kreps (1990). 
firm's objective function as the starting point of our analysis or do we need to dig deeper and derive the behavior of the firm from its governance structure, incentives of managers, culture, etc.? Spulber's book takes the former approach but I think that progress is more likely to be made with the latter.

\section{REFERENCES}

-Acemoglu, Daron, Philippe Aghion, Claire Lelarge, John Van Reenen, and Fabrizio Zilibotti. 2007. "Technology, Information, and the Decentralization of the Firm." Quarterly Journal of Economics, 122(4): 1759-99.

-Aghion, Philippe, and Jean Tirole. 1997. "Formal and Real Authority in Organizations." Journal of Political Economy, 105(1): 1-29.

Alchian, Armen A., and Harold Demsetz. 1972. "Production, Information Costs, and Economic Organization.” American Economic Review, 62(5): 777-95.

-Alonso, Ricardo, Wouter Dessein, and Niko Matouschek. 2008. "When Does Coordination Require Centralization?” American Economic Review, 98(1): 145-79.

-Baker, George P. 1992. "Incentive Contracts and Performance Measurement." Journal of Political Economy, 100(3): 598-614.

- Baker, George P., Robert Gibbons, and Kevin J. Murphy. 1999. "Informal Authority in Organizations." Journal of Law, Economics, and Organization, 15(1): 56-73.

Bebchuk, Lucian, and Jesse Fried. 2004. Pay without Performance: The Unfulfilled Promise of Executive Compensation. Cambridge and London: Harvard University Press.

Berle, Adolf A., and Gardiner C. Means. 1932. The Modern Corporation and Private Property. New York: Harcourt, Brace \& World.

Bloom, Nicholas, and John Van Reenen. 2007. "Measuring and Explaining Management Practices across Firms and Countries." Quarterly Journal of Economics, 122(4): 1351-1408.

Bolton, Patrick, and Mathias Dewatripont. 1994. "The Firm as a Communication Network." Quarterly Journal of Economics, 109(4): 809-39.

-Bolton, Patrick, and Mathias Dewatripont. 1995. “The Time and Budget Constraints of the Firm." European Economic Review, 39(3-4): 691-99.

Bolton, Patrick, and Mathias Dewatripont. 2005. Contract Theory. Cambridge and London: MIT Press.

Bubb, Ryan, and Alex Kaufman. 2009. "Consumer Biases and Firm Ownership." http://www.people. fas.harvard.edu/ ryanbubb/papers/BubbKaufman_ ConsumerBiasesandFirmOwnership.pdf.

Chandler, Alfred D., Jr. 1977. The Visible Hand: The Managerial Revolution in American Business. Cambridge and London: Harvard University Press.

Chandler, Alfred D., Jr. 1990. Scale and Scope: The
Dynamics of Industrial Capitalism. Cambridge, Mass. and London: Harvard University Press, Belknap Press.

-Coase, Ronald H. 1937. "The Nature of the Firm." Economica, 4(16): 386-405.

-Coase, Ronald H. 1960. "The Problem of Social Cost." Journal of Law and Economics, 3(1): 1-44.

-Dessein, Wouter. 2002. "Authority and Communication in Organizations." Review of Economic Studies, 69(4): 811-38.

Fisher, Irving. 1930. The Theory of Interest. New York: Macmillan.

Garicano, Luis. 2000. "Hierarchies and the Organization of Knowledge in Production." Journal of Political Economy, 108(5): 874-904.

-Glaeser, Edward L., and Andrei Shleifer. 2001. "Notfor-Profit Entrepreneurs.” Journal of Public Economics, 81(1): 99-115.

-Grossman, Sanford J., and Oliver Hart. 1986. "The Costs and Benefits of Ownership: A Theory of Vertical and Lateral Integration." Journal of Political Economy, 94(4): 691-719.

Hansmann, Henry. 1996. The Ownership of Enterprise. Cambridge and London: Harvard University Press, Belknap Press.

-Hart, Oliver. 2008. "Reference Points and the Theory of the Firm.” Economica, 75(299): 404-11.

-Hart, Oliver. 2009. "Hold-Up, Asset Ownership, and Reference Points." Quarterly Journal of Economics, 124(1): 267-300.

- Hart, Oliver, and Bengt Holmstrom. 2010. "A Theory of Firm Scope." Quarterly Journal of Economics, 125(2): 483-513.

-Hart, Oliver, and John Moore. 1990. "Property Rights and the Nature of the Firm." Journal of Political Economy, 98(6): 1119-58.

-Hart, Oliver, and John Moore. 1996. “The Governance of Exchanges: Members' Cooperatives versus Outside Ownership." Oxford Review of Economic Policy, 12(4): 53-69.

-Hart, Oliver, and John Moore. 2008. "Contracts as Reference Points." Quarterly Journal of Economics, 123(1): 1-48.

-Hart, Oliver, Andrei Shleifer, and Robert W. Vishny. 1997. "The Proper Scope of Government: Theory and an Application to Prisons." Quarterly Journal of Economics, 112(4): 1127-61.

-Holmstrom, Bengt. 1979. "Moral Hazard and Observability.” Bell Journal of Economics, 10(1): 74-91.

-Holmstrom, Bengt. 1982. "Moral Hazard in Teams." Bell Journal of Economics, 13(2): 324-40.

-Holmstrom, Bengt, and Paul Milgrom. 1987. "Aggregation and Linearity in the Provision of Intertemporal Incentives." Econometrica, 55(2): 303-28.

Holmstrom, Bengt, and Paul Milgrom. 1991. "Multitask Principal-Agent Analyses: Incentive Contracts, Asset Ownership, and Job Design." Journal of Law, Economics, and Organization, 7(Special Issue): 24-52.

-Jensen, Michael C., and William H. Meckling. 1976. "Theory of the Firm: Managerial Behavior, Agency 
Costs and Ownership Structure." Journal of Financial Economics, 3(4): 305-60.

Jensen, Michael C., and William H. Meckling. 1992. "Specific and General Knowledge, and Organizational Structure." In Contract Economics, ed. Lars Werin and Hans Wijkander, 251-74. Cambridge, Mass. and Oxford: Blackwell.

-Klein, Benjamin, Robert G. Crawford, and Armen A. Alchian. 1978. "Vertical Integration, Appropriable Rents, and the Competitive Contracting Process." Journal of Law and Economics, 21(2): 297-326.

Kreps, David M. 1990. "Corporate Culture and Economic Theory." In Perspectives on Positive Political Economy, ed. James E. Alt and Kenneth A. Shepsle, 90-143. Cambridge; New York and Melbourne: Cambridge University Press.

Lafontaine, Francine, and Margaret Slade. 2007. "Vertical Integration and Firm Boundaries: The Evidence." Journal of Economic Literature, 45(3): 629-85.

La Porta, Rafael, Florencio Lopez-de-Silanes, and Andrei Shleifer. 1999. "Corporate Ownership around the World." Journal of Finance, 54(2): 471-517.

Levin, Jonathan, and Steven Tadelis. 2005. "Profit Sharing and the Role of Professional Partnerships." Quarterly Journal of Economics, 120(1): 131-71.

Marschak, Jacob, and Roy Radner. 1972. Economic Theory of Teams. New Haven and London: Yale University Press.

-Mirrlees, James A. 1999. "The Theory of Moral Hazard and Unobservable Behaviour: Part I." Review of Economic Studies, 66(1): 3-21.

Modigliani, Franco, and Merton H. Miller. 1958. "The Cost of Capital, Corporation Finance and the Theory of Investment." American Economic Review, 48(3): 261-97.

Morck, Randall, Andrei Shleifer, and Robert W. Vishny.
1988. "Management Ownership and Market Valuation: An Empirical Analysis." Journal of Financial Economics, 20(1-2): 293-315.

Nicholson, Walter, and Christopher Snyder. 2006. Intermediate Microeconomics and Its Application, Tenth edition. Mason, Ohio: Thomson South-Western.

Radner, Roy. 1992. "Hierarchy: The Economics of Management." Journal of Economic Literature, 30(3): 1382-1415.

Radner, Roy, and Timothy Van Zandt. 1992. "Information Processing in Firms and Returns to Scale." Annales d'Economie et de Statistique, 25-26: 265-98.

Rajan, Raghuram G., and Luigi Zingales. 1998. "Financial Dependence and Growth.” American Economic Review, 88(3): 559-86.

Roberts, John. 2004. The Modern Firm: Organizational Design for Performance and Growth. Oxford and New York: Oxford University Press.

The Economist. 2007. "Mergers and Acquisitions." January 13. http://www.economist.com/node/8522024.

Tirole, Jean. 1986. "Hierarchies and Bureaucracies: On the Role of Collusion in Organizations." Journal of Law, Economics, and Organization, 2(2): 181-214.

Tirole, Jean. 1988. The Theory of Industrial Organization. Cambridge, Mass. and London: MIT Press.

Ward, Benjamin. 1958. "The Firm in Illyria: Market Syndicalism." American Economic Review, 48(4): $566-89$.

Williamson, Oliver E. 1971. "The Vertical Integration of Production: Market Failure Considerations." American Economic Review, 61(2): 112-23.

Williamson, Oliver E. 1975. Markets and Hierarchies: Analysis and Antitrust Implications. New York: Free Press.

Zwiebel, Jeffrey. 1996. "Dynamic Capital Structure under Managerial Entrenchment." American Economic Review, 86(5): 1197-1215. 